\title{
OS DIAS E OS GESTOS: UMA VIAGEM
}

Leandro Belinaso ${ }^{1}$

Não conheciam nada que não fosse frágil e confuso.
No entanto, era a vida deles, era a fonte de
exaltações desconhecidas, mais que inebriantes, era
alguma coisa de imensamente, de intensamente
aberto.
Georges Perec

Quatro horas da madrugada e o despertador do celular toca. A sensação de não saber o que se passa invade o instante. Levanto e o mundo chega em um segundo. Parto rumo à São João del-Rei, Minas Gerais, para o VII Encontro do Grupo de Pesquisa em Educação, Filosofia e Imagem (GEFI).

\section{Dia 1}

A malemolência do corpo amanhecido acompanha o começo do deslocamento. Lembro, na duração do percurso aéreo, de uma fotografia de Luiz Braga vista pela primeira vez em uma visita recente à Pinacoteca, em São Paulo. Recordo o gesto que lança a menina debruçada em uma janela a um mundo desconhecido. Ela está ali sem retesar músculo algum, como se nada pudesse desfazer a entrega do corpo ao presente que o inscreve à vida. Sob luz verde da imagem, a menina descansa ${ }^{2}$.

****

Para amaciar cada fibra da musculatura que nos faz, como conceitua Éden Peretta (2012) a partir da dança butô de Tatsumi Hijikata, "corpo de carne" - receptáculo de memórias e fluxo de sensações - está um encontro a suspender do cotidiano o agito e a aceleração inflamatórias. Sinto-me conectado à lentidão da menina em verde da fotografia, em seu gesto alheio ao ruído cotidiano $^{3}$. Recentemente havia guardado na estante da minha biblioteca - adoro dizer que tenho uma, mas ela é singela e vai lançando seus tentáculos e ocupando cada canto do pequeno apartamento que resido - o livro de Kazuo Ohno (2016), depois dele habitar por meses o criado mudo ao lado da cama. Neste momento presente da escrita do ensaio me recordo de uma passagem que parece dizer da fotografia.

Não podemos nos movimentar o tempo todo. Movimentar e descansar; de repente, surge um espaço minúsculo. Um espaço onde descansamos e a partir do qual, pouco a pouco, ascendemos. Há um espaço de liberdade para descansar. Não precisamos nos mover o tempo todo, há esse cantinho (p. 36).

Luiz Braga trouxe ao mundo da imagem a delicadeza do gesto de um corpo em descanso, mesmo que entregue à dureza da janela azulejada, do sólido balcão da venda, do concreto do aparador da sala de estar transformada em dispensa. É possível descansar antes do próximo

\footnotetext{
${ }^{1}$ Professor da Universidade Federal de Santa Catarina.E-mail: lebelinaso@gmail.com.

${ }^{2}$ A fotografia "Menina em verde", de 2003, pode ser contemplada no site do artista: $\langle$ http://www.luizbraga.fot.br $>$.

${ }^{3}$ Em outro ensaio, Belinaso (2016), rascunhei argumentos sobre a potência da escrita com os ruídos do mundo.
} 
combate, da brincadeira seguinte, do riso que chegará. Um encontro dançante sob uma luz verde começa e amacia nosso "corpo de carne". Só tenho gratidão às minhas queridas amigas e colegas do GEFI.

\section{Dia 2}

O encontro já está, aqui no ensaio, em seu segundo dia [ou seria o segundo dia da escrita do ensaio?] e nem falei muito sobre o primeiro. Talvez seja preciso ainda comentar sobre a sensação da chegada à São João del-Rei. Havia estado na cidade no último ano do século passado, em 1999. Viajei de férias com um casal de amigos. Morava em Porto Alegre. Foi a primeira vez que voei. Uma aeronave da Vasp. Apavorante. Disso lembro bem. O estranho, agora, foi desconhecer São João. Nada ali parecia fazer parte de algum lugarzinho recôndito da minha memória. Como é possível percorrer um lugar já visitado como se estivesse nele pela primeira vez? Foi assim que me senti no pedaço da manhã do segundo dia em que sai pela cidade andando sozinho.

Em uma instalação artística intitulada "Memory", Anish Kappor nos provoca pensar que a memória jamais pode ser acessada por inteiro, mas se produz através dos fragmentos que juntamos ficcionalmente, como cacos, para compor uma narrativa inteligível de algum momento vivido. Este ensaio parte desse entendimento para sua composição gestual. Em "Memory", exibida entre setembro de 2009 e janeiro de 2010 no Museu Guggenheim de Nova York, os expectadores não enxergavam completamente a imensa e pesada escultura assemelhada a uma bola de ferro oval. Era preciso mover-se pelos andares do prédio para ter visões parciais da mesma e imaginar seu interior, cuja entrada podia ser testemunhada, mas não experimentada. A obra sugeria uma nova percepção do espaço e de suas escalas, sendo que só era possível reconstruí-la pelas imagens fragmentadas e fugidias que passavam a habitar e a desabitar, ao mesmo tempo, a memória de cada visitante.

$* * *$

Tenho mania de procurar lojas que ainda teimam em vender discos e encontro uma no centro histórico de São João del-Rei, pequena, que guarda um CD de Luiz Melodia chamado "Felino", de 1983. A singela preciosidade que tenho em mãos havia sido relançada em 1996 data da sua fabricação no pólo industrial de Manaus. Está em estado de nova. Há mais de vinte anos me espera. Levo sem pensar, como se houvesse outra opção, juntamente com o último CD de Zeca Baleiro, intitulado "Era domingo" e lançado em 2016.

Neste disco de Luiz Melodia há uma canção singela e arrebatadora. Uma das que mais gosto do artista e que não está em sua obra-prima [se é que isso existe] que, a meu ver, é o disco "Pérola Negra", de 1973. Ela nos lembra da importância do encontro, que nos potencializa uma imprescindível sensação de coletivização e nos alerta que "mesmo se tudo juntar por aí, em nós, o só [sempre cantei $o$ sol] há de sempre existir". Termino a escrita desse segundo dia com o gesto trazido pelo poema da canção.

Tava naquela que dá dó

Olhando a lua andar só

Gota de chuva, nota dó

Sinto o tempo descontente ao redor

Como o puro alimento dessa horta

Mesmo se tudo juntar por aí

Em nós, o só há de sempre existir 


\section{Dia 1}

Jamais esquecerei os abraços e os beijos trocados na chegada a São João del-Rei por entre as grades de um portão lateral da igreja de São Francisco de Assis. Do lado de dentro, no pátio, parte das pessoas estão se juntando e se preparando para sair em caminhada pela cidade em uma oficina de fotografia ministrada pela artista Marli Wunder. Parte de nós, ao lado da rua, nos deslocamos para almoçar após chegar de uma longa viagem. É o começo da tarde. Um sol escaldante brilha na secura da região. A paisagem se pinta de tons alaranjados. O céu, de tão azul, dói. A grade não impede um gesto de alegria pelo encontro entre nossos corpos, presentes.

Um gesto, aliás, sem propósito. Sem objetivo. Sem finalidade. Apenas a ressoar a alegria potente do encontro. E aqui começo a pensar com Giorgio Agamben (2015). O filósofo argumenta que o "gesto é a exibição de uma medialidade, o tornar visível um meio como tal" (p. 59). O gesto não tem nada a dizer, não tem êxito na linguagem. É um gaguejar. Improvisação. Para atentar-se aos gestos, percorrendo a superfície dos processos educativos e formativos, dos encontros, é preciso suspender finalidades. Deixar-se tocar pelos gestos para tornar visíveis os meios enquanto tais. Habitar o meio de todo começo. Dar a ver o gesto.

Michel Foucault (2016a), ao comentar um livro de ficção assinado por Jacques Almira e intitulado "Le Voyage à Naucratis [que, aliás, nunca li]", diz que o escritor "fabrica mais coisas a ver. Com palavras, frases, ele decompõe, recompõe, constrói, e, bruscamente, você tem um gesto..." (p. 55, os itálicos são meus). Com o esforço braçal da ficção, da literatura, se tem, apenas, um gesto.

Não se trata neste brevíssimo ensaio de traçar uma genealogia, uma filosofia do gesto algo que está para além da minha capacidade. Desejo apenas rascunhar a ideia de que um gesto pode nos arremessar e nos dissolver em um ínfimo, silencioso, invisível, gaguejante meio. E é nessa provocação poética e dançante que a ficção - e este ensaio é um esforço de ficção poderia nos arrebatar e nos lançar às forças inumanas que nos atravessam, nos constituem e potencializam eticamente em nós a fabricação de coisas a ver a respeito de um encontro como o que vivemos por três dias em São João del-Rei.

Como diz Foucault (2016b), em um fragmento de uma conferência proferida em Belo Horizonte, em 1973, “a literatura [a ficção] é a localidade onde o homem desaparece em benefício da linguagem. Ali onde aparece a palavra, o homem cessa de existir” (p. 50). Podemos pensar, quem sabe, na educação como um gesto de ficção para que possamos nela existir e, ao mesmo tempo, nela desaparecer para que coisas a ver se mostrem. Para o combate aos fins do mundo inclusive - há o gesto descansado da alegria de um encontro.

\section{Dia 3}

A seção anterior terminou como se já estivesse tecendo as conclusões do ensaio. Mas ainda tenho um terceiro dia para escrever e inscrever aqui no texto. Tenho que dizer algo sobre o teatro assistido ou o sarau de poesias vivido. Um pouco sobre os super-heróis ou as imagens do estudar. Algo a respeito das conversas miúdas, dos silêncios, das risadas, das cantorias, das goiabadas, dos queijos. Das muitas águas bebidas que aplacam a secura do tempo. E começo a imaginar uma inundação. Um dilúvio. E lembro de um romance mínimo de João Gilberto Noll (2015) intitulado "A presença".

Se passasse na rua da Praia, entrava na livraria Ventura. Lá ficava o poeta com aquelas crianças em volta. Dessa vez a fotografia não estava ali. No instante de se dar conta da ausência, aproximou-se um homem a lhe pedir uns trocados. 
Sem trabalho, não tinha para a condução. Ele, sem querer, desconversou: "E Walt Whitman, você leu"? Pois era o poeta preferido do desempregado. Sentia falta do retrato dele com as crianças, ali. E apontou para o claro na parede. Foi quando um trovão cortou o fio da tarde. Eles já estavam ilhados (p. 246 e 247).

\section{Dias posteriores à viagem, como todos os outros}

O que escrever sobre três dias vividos em um evento acadêmico? Descrever o que nele se aprendeu, viu, recolheu de referências bibliográficas? Preferi percorrer os dias e perceber, neles, alguns gestos. Isso me fez escrever sobre desutilidades. Estou impregnado do poeta Manoel de Barros, que li efusivamente desde o começo de 2017. Gestos esvoaçantes que embalaram os abraços da chegada em meio a uma grade. Gestos brincantes diante do disco de um artista que já não está. Gestos de inundação, que me levaram a Noll e seus romances mínimos.

Recordei outras viagens através do ensaio. A que fiz à Nova York em 2009. Do tempo que passei sozinho dentro de um museu incrível me esforçando para apreender uma obra gigantesca ali instalada. Lembro da viagem que me fez perambular por Minas Gerais com um casal de amigos que já não são mais casal, embora sigam sendo amigos um tanto quanto distantes. Rememorei meu primeiro deslocamento de avião. Descobri que viajar para uma cidade significa ter que, um dia, retornar. Mesmo assim você seguirá desconhecendo-a.

Nada que nos move a escrever é desimportante. Mas cada palavra elegida e frase tecida carrega uma ética, um desejo de mundo. Escrever para se tornar um pouco mais sensível e atento. Eis uma urgência. Minha escrita [minha?] tem estado cada dia mais concisa. Vontade crescente de silêncio. Cada repertório lembrado, nessa profusão cultural que me atravessa, foi trazido ao ensaio. Procuro não soterrar aquilo que faz meus dedos musicarem um teclado. Quis seguir a dica de Luciano Bedin da Costa (2017):

Pensar a escrita e a leitura enquanto gestos de resistência implica em não apenas responder aos ditames desses tempos-textos-mercadoria, mas em instaurar-lhes vacúolos de silêncio, zonas de dispersão e desvio que possam fazê-los tomar outros cursos, excursionar" (p. 18).

Talvez os dias vividos no encontro em São João del-Rei merecessem mais, muito mais, do que consegui escrever com esse ensaio. Escrevi em somente três dias. Nem mais, nem menos. Essa foi a regra que criei. E de repente tudo me pareceu tão frágil e confuso. Havia algo imenso a ser dito. Intensamente aberto. E só me foi possível um gesto de escrita.

\section{Referências}

AGAMBEN, Giorgio. Meios sem fim: notas sobre a política. Tradução de Davi Pessoa Carneiro. Belo Horizonte: Autêntica, 2015.

BELINASO, Leandro. Como escrever com os ruídos do mundo? In: CHAVEZ, Silvia; BRITO, Maria dos Remédios de (Org.). Formação, ciência e arte: autobiografia, arte e ciência na docência. São Paulo: Livraria da Física, 2016. Disponível em: 〈http://bit.ly/2yrq919>.

COSTA, Luciano Bedin. Ainda escrever: 58 combates para uma política do Texto. São Paulo: Lumme Editor, 2017. 
FOUCAULT, Michel. Foucault, o filósofo, está falando: pense. In: Ditos e Escritos. Organização e seleção de textos de Manoel Barros da Motta. Tradução de Vera Lucia Avellar Ribeiro. Rio de Janeiro: Forense Universitária, 2016a. v. VII

FOUCAULT, Michel. A festa da escritura. Pense. In: Ditos e Escritos. Organização e seleção de textos de Manoel Barros da Motta. Tradução de Vera Lucia Avellar Ribeiro. Rio de Janeiro: Forense Universitária, 2016b. v. VII

NOLL, João Gilberto. Mínimos, múltiplos, comuns. Rio de Janeiro: Record, 2015.

OHNO, Kazuo. Treino e(m) poema. Tradução de Tae Suzuki. São Paulo: n-1 edições, 2016.

PEREC, Georges. As coisas: uma história dos anos sessenta. Tradução de Rosa Freire d'Aguiar. São Paulo: Companhia das Letras, 2012.

PERETTA, Éden. Memórias e políticas do "corpo de carne" no Ankoku Butô de Tatsumi HIjikata. In: VII CONGRESSO DA ABRACE - ASSOCIAÇÃO BRASILEIRA DE PESQUISA E PÓS-GRADUAÇÃO EM ARTES CÊNICAS, 2012, Porto Alegre. Anais... 